\title{
Maize Hybrids Yield as Affected by Inter and Intra Row Spacing
}

\author{
A. A Kandil, A. E. Sharief*, A. M. A. Abozied \\ Department of Agronomy, Faculty of Agriculture, Mansoura University, Egypt \\ * Corresponding Author: Prof. Ali Sharief Agronomy Dept., Fac. of Agric., Mansoura University, Egypt, 35516 El- \\ Mansoura, Egypt Tel: +201222986347 Fax: +2052221688,
}

\begin{abstract}
To study the effect of different, inter and intrarow on some new maize hybrids under on yield and its components. Two field experiments were carried out during summer seasons of 2014 and 2015. The results showed that highest ear length, ear diameter, grains weight/ear, shelling percentage, 100-grain weight and grain yield/fed. S.C 2055 hybrid was recorded the greatest value number of rows/ear. S.C 2066 hybrids recorded the highest number grains/row, the lowest ear length, ear diameter, grains weight/ear, shelling percentage and 100-grain weight. Sown maize plants in width rows $(70 \mathrm{~cm})$ produced the highest number of ear/plant, number of rows/ear and number grains/row and ear length, ear diameter, grains weight/ear, shelling percentage and 100-grain weight. Sown maize plants in hills $30 \mathrm{~cm}$ apart produced the greatest numbers of ears/plant and thick ears, highest grains weightlear, shelling percentage and 100- grain weight. However, sown maize plants at hill spacing of $25 \mathrm{~cm}$ apart produced tallest ears. It could be concluded that sown S.C. 3084 hybrid at $60 \mathrm{~cm}$ row width and hill spacing of $20 \mathrm{~cm}$ apart maximized maize productivity under the environmental conditions of Dakahlia Governorate, Egypt.
\end{abstract}

Keywords-Row spacing, hill spacing maize yield, yield components.

\section{INTRODUCTION}

Maize (Zea mays L.) is considered as a one of the most important strategic cereal food crops in Egypt and the world. Recently, is mixed with wheat flour for making bread to reduce the gap between production and consumption of wheat. There is agonizes from the shortage of cereal production such maize. To intensification grain corn production per unit area of maize in Delta soils in Egypt, it must be resolute the appropriate maize hybrids at both row and hill spacing to exploit its productivity. Maize hybrids may be dissimilar in agronomic characters due to row width, hill spacing and plant population density that affect production per unit area. Maize hybrids differed with different row spacing, plant population and hill spacing. Maize hybrids differences on agronomic characters and grain yield. In this respect, $[1,2]$ summarized that for obtaining a higher maize yield and net income, maize hybrids had different responses to agronomic characters and grain yield. [3, 4] showed a significant difference between maize hybrids in plant height, No. of ear/plant, barren \%, LAI, No. of kernels/row, grain weight/ear and grain yield/plant. [5] initiate that hybrid 30 Y 87 was early in maturity, produced more No. of grain row/cob, less No. of grains /row and less cob length than the hybrid 31R88 similarly 1000grain weight, grain yield and straw yield of hybrid 30 Y 87 was significantly greater than the hybrid 31R88. [6] noticed that hybrid SiPAA-444 surpassed hybrid Ts-13 for grain yield. [7] found that S.C. 128 produced the highest value when planting in ridges $80 \mathrm{~cm}$ apart $22 \mathrm{~cm}$ between hills and one plant hill. [8] set up that hybrid 9022-13 was superior to other varieties investigated. $[9,10]$ concluded that maize hybrid S.C. 10 with $429 \mathrm{Kg} \mathrm{N} / \mathrm{ha}$, recorded the tallest cob. Also, hybrid S.C. 10 gave the maximum 1000-kernel weight and grain yield. [11,12] showed that maize hybrid significantly differed in final grain yield and some yield components as cob yield and number of grains/cob. [13] indicated that maize hybrids DKC6589 and Mobeen had the highest and lowest grain yield among studies hybrids. Higher grain yield in DKC6589 was due to the higher number of grains /ear and 100-grain weight. [14] found that number of ears per $\mathrm{m}^{-2}$ of SC 320 hybrid was significantly higher than SC 301 hybrid, but number of grains/ear and 1000-grain weight in SC 320 hybrid was significantly lower than SC301 hybrid. [15,16] showed that the harvests performed after physiological maturity decreased the real grain productivity, especially for the hyper-early hybrids. Row width plays a great effect on the maize plant population. In this respect, $[17,18]$ designated that increasing distance between rows from 60 to 70 and 80 $\mathrm{cm}$ lead to a significant increase in growth character, grain and its components due to better interception and utilization of solar radiation and the increase in photosynthetic processes. [2,19] showed that increasing 
ridge spacing significantly recorded No. of days to $50 \%$ tassling and silking, plant and ear heights were in some direction, planting on the $80 \mathrm{~cm}$ ridge was associated with a significant increase in ear length No. of kernels/row, 1000 kernel weight and grain yield. [2,20] point out that planting maize in ridges 80 or $90 \mathrm{~cm}$ apart produced the highest values of all studied characters. Planting maize in ridges $70 \mathrm{~cm}$ apart gave the lowest values of these characters. Recently, [21] reported that maize plants sown in line having $(60 \mathrm{~cm})$ row to row distance had highest plant, heavier 1000 grains weight and highest grain yield. Growth and grain yield of maize is more affected by variations in hill spacing than other members of the grass family. Hill spacing affected of agronomic, flowering characteristics, and grain yield. Many investigators studied the effect of plant density of maize as a spacing between hills, in this regard, [1,2] described that highest grain yield and harvest index obtained at 10 plants $/ \mathrm{m}^{2}$. The highest No. of the grain/ear, stem diameter and cob length were recorded at 8 plants $/ \mathrm{m}^{2}$, while the highest values of plant height were recorded at 12 plants $/ \mathrm{m}^{2}$. $[22,23]$ establish that grain yield increased in the narrow rows due to limited intra-row plant competition for light, nutrients and water. Population above the optimum has resulted in lodging that has caused a reduction in maize production. [1,7] showed that increase in intra-row spacing from 20 to $25 \mathrm{~cm}$ significantly increased No. of row /cob, cob diameter, 100-grain weight and grain yield. [9] reported that highest grain yields for some hybrid was obtained at plant denser of 8 plants $/ \mathrm{m}^{2}$ reached their maximum grain yield and increased density in the grain yield and its components. Therefore, the best option to achieve the highest grain yield. [24] showed that the $70 \mathrm{x}$ 30 and $60 \times 40 \mathrm{~cm}$ spacing gave higher values of the morphological parameters than $80 \times 20 \mathrm{~cm}$. With regard to yield, $80 \times 20 \mathrm{~cm}$ gave the highest average cob weight and 1000-grain weight. With respect to the interaction between maize hybrids and row width will present in this respect, [21] described that Hybrid-3025 sown in ridges having a $60 \mathrm{~cm}$ row to distance produce more grain yield as compared to Azam variety. Concerning the interaction among maize hybrids and hill spacing, in this respect, $[25,26]$ concluded that maize hybrids react differently to various plant population densities. The interaction between the spaces between the hills and maize hybrids was significant for ear length and grain yield. Regarding to the interaction between row width and hill spacing, in this respect, [27] decided that this interaction had a significant for number of ear/plant, grain yield/plant and per faddan. They added that planting maize on $80 \mathrm{~cm}$ rows of plant densities of 25-30 thousand plants/fed (17$20 \mathrm{~cm}$ between hills) maximized grain yield. Concerning to the interaction among maize hybrids, row width and hill spacing, in this respect, [1,28] described that the highest grain yield due to increased plant population and reduced row spacing, depended mainly on different factors, like the hybrid type in use. Therefore, the present investigation was objective to study inter- intra-row spacing and plant population density on the growth, yield and yield components of some single cross maize hybrids.

\section{MATERIALS AND METHOD}

\subsection{Research time and location:}

The current investigation was carried out in the extension field at Mahelt Engaq Village, Sherbin Center, Dakahlia District during summer growing seasons of 2014 and 2015 to study the effect of inter and intra-row spacing on plant growth, yield, and yield components of some maize hybrids. Two separate field trials were conducted during each year of 2014 and 2015 summer seasons. One trail for each row spacing (RS), i.e. 60 and $70 \mathrm{~cm}$ between ridges. The experimental design used in each trail was split-plot design with four replications. The main plots were assigned for maize hybrids i.e. (SC) 3084, (SC) 3062, (SC) 2055 and (SC) 2066 and hill spacing were randomly distributed in the sub-plots i.e. 15, 20, 25 and $30 \mathrm{~cm}$ hill spacing apart. Each plot consisted of five ridges, $4.5 \mathrm{~m}$ long and the ridge width was differed according to the treatment. The combined analysis was done over the two row pacing experiments. Eight plant population densities and its distribution were the combination of four hybrids and four plant spacing. The outer two ridges $\left(1^{\text {st }}\right.$ and $\left.5^{\text {th }}\right)$ were considered as borders. Grain yield and yield components were determined from the remaining two ridges. The previous crop was wheat in both years. Planting date was done on June 16 in the 2014 season, and June 6 in the 2015 season. Calcium superphosphate $15.5 \% \mathrm{P}_{2} \mathrm{O}_{5}$ at the rate of $480 \mathrm{~kg} / \mathrm{ha}$ was applied before planting. Three grains were hand planted in each hill, then thinning to one plant per hill was done before the first irrigation. Hoeing twice was done for controlling weeds before the first and second irrigations. Nitrogen fertilizer in the form of urea $(46.0 \% \mathrm{~N})$ at the rate of $288 \mathrm{~kg} / \mathrm{ha}$ was applied in two equal doses before the first and the second irrigations, respectively. Recommended agricultural practice in the region was applied. These distributed of eight plant population densities was presented in Table 1.

\subsection{Studied Characters:}

At harvest (after 120 days from planting) random samples of guarded ten plants were taken at random from each sub - plot to determine the yield components. Number of ears/plant was calculated as the mean number of ears of ten plants. Ear length $(\mathrm{cm})$ was measured as the means of ten ears length. Ear diameter $(\mathrm{cm})$ was measured by using 
a Vernier Caliper as the means of ten ears randomly. Number of rows/ear was counted as the average of the number of rows of ten ears randomly. Number of grains/row was counted as the means of a number of grains in each row of ten ears randomly. Ear grains weight ( $g$ ) was obtained by averages weight of ten ear grains in grams. Shelling percentage $(\%)$ was determined by dividing the weight of ten ears shelled grains by their weight and multiplied by 100 . 100-grain weight (g) was taken from clear grains and determined as the mean weight of four random samples of 100 grains of each plot and adjusted to $15.5 \%$ moisture content. Grain yield/ha was determined by the weight of grains per kilograms adjusted to $15.5 \%$ moisture content of each plot, then converted to $\mathrm{t} / \mathrm{ha}$.

\subsection{Experimental analysis:}

All obtained data were statistically analyzed according to the technique of analysis of variance (ANOVA) for the split - plot design to each experiment (row spacing), then combined analysis was done between row spacing trails as published by [29] by using "MSTAT-C" computer software package. A Least significant of the difference (LSD) method was used to test the differences between treatment means at the $5 \%$ level of probability as described by [30].

\section{RESULTS}

\subsection{Effect of row width:}

Regarding to the effect of row width $(60$ and $70 \mathrm{~cm}$ between ridges) number of ear/plant, ear length, ear diameter, number of rows/ear, number of grains/row, ear grains weight, shelling percentage, 100-grain weight and grain yield/ha, the results in Tables 2 and 3 clearly showed a significant difference in both seasons due to row width. Sown maize plants in width rows $(70 \mathrm{~cm})$ produced the highest number of ear/plant, number of rows/ear and number grains/row and ear length, ear diameter, grains weight/ear, shelling percentage and 100grain weight. Sown maize plants on narrow row width (60 $\mathrm{cm}$ ) produced the highest values of grain yield/ha. This may be due to increases in photosynthesis due to increase light penetration through maize canopies.

\section{2. Performance of maize hybrids:}

A significant difference among four yellow maize hybrids i.e.SC 3084, SC 3062, SC 2055 and SC 2066 on number of ear/plant, ear length, ear diameter, number of rows/ear, number of grains/row, ear grains weight, shelling percentage, 100-grain weight and grain yield/ha in both seasons as shown in Tables 2 and 3. The results showed that highest ear length, ear diameter, grains weight/ear, shelling percentage, 100-grain weight and grain yield/ha. S.C 2055 hybrid was recorded the greatest value number of rows/ear. However, S.C 2066 hybrids recorded the highest number grains/row, the lowest ear length, ear diameter, grains weight/ear, shelling percentage and 100grain weight. S.C 3062 hybrid was recorded the lowest values of grain yield in both seasons. While, S.C 3084 hybrids recorded the lowest number of ear/plant and number grains/row.

\subsection{Effect of hill spacing:}

Concerning to the effect of hill spacing (15, 20, 25 and $30 \mathrm{~cm}$ hill spacing apart) on number of ear/plant, ear length, ear diameter, number of rows/ear, number of grains/row, ear grains weight, shelling percentage, 100grain weight and grain yield/ha, the results in Tables 3 and 2 clearly indicated that hill spacing significantly affected these traits in both seasons. Sown maize plants in hills $30 \mathrm{~cm}$ apart produced the greatest numbers of ears/plant and thick ears, highest grains weight/ear, shelling percentage and 100- grain weight. However, sown maize plants at hill spacing of $25 \mathrm{~cm}$ apart produced tallest ears. On the other side, sown maize plants at $15 \mathrm{~cm}$ apart produced the greatest number of rows/ear, the number grains/row and highest grain yield/ha.

\subsection{Interaction effects:}

Results in Tables 2 and 3 indicated that there was no significant interaction between maize hybrids and row width on number of ear/plant, ear length, ear diameter, number of rows, number of grain/rows and grain weight/ear. However, the effective interaction between maize hybrids and row width on the 100 grain weight and grain yield/ha significant effected on these traits in both seasons. The interaction between maize hybrids and row width on ear diameter the highest weights of 100 grain weight and grain yield/ha were produced from sown S.C.3084 at 70 and $60 \mathrm{~cm}$, respectively as shown in Figs. 1 and 2. Results in Tables 2 and 3 indicated that there was no significant the interaction between maize hybrids and hill spacing of number of ear/plant, ear length, ear diameter, number of rows, number of grains/rows and grain weight/ear. However, the statistical analysis showed a significant interaction between maize hybrids and hill spacing on the 100 grain weight and grain yield t/ha. The results showed that highest interaction of 100 grain weight from S.C. 3084 at $30 \mathrm{~cm}$ apart as graphically shown in Fig. 3. Highest grain yield/ha from sown S.C. 3084 in $20 \mathrm{~cm}$ hill spacing as illustrated in Fig. 4. Results in Tables 2 and 3 indicated that there was insignificant of the interaction between row width and hill spacing of number of ear/plant, ear length, ear diameter, number of rows, number of grains/rows and grain weight/ear. The results showed that highest interaction between row width and hill spacing on 100 grain weight was obtained from sown at $70 \mathrm{~cm}$ row width and $30 \mathrm{~cm}$ hill spacing as 
shown in Fig. 5. Highest grain yield/ha was produced from sown at $70 \mathrm{~cm}$ row width and $20 \mathrm{~cm}$ hill spacing as illustrated in Fig. 6. Concerning the third interaction among three studied factors, i.e. maize hybrids, row width and hill spacing, in significantly affected on all studied characters in both seasons.

\section{DISCUSSION}

The results revealed a significant difference in both seasons due to row width. The increases in those yield components contributed to the higher productivity presented by narrowing sown maize. Therefore, the larger availability of solar radiation probably allowed plants to set more grains per ear and to produce heavier grains. These results in good accordance with those reported by [2,17,20,21,27]. The difference among four yellow maize hybrids i.e. SC 3084, SC 3062, SC 2055 and SC 2066 on number of ear/plant, ear length, ear diameter, number of rows/ear, number of grains/row, ear grains weight, shelling percentage, 100-grain weight and grain yield/ha. The differences in yield and yield components due maize hybrids may be due to the genetic factors. These results in good agreement with those reported by $[2,4,11,12,13,14,16,27$,$] . Hill spacing significantly$ affected number of ear/plant, ear length, ear diameter, number of rows/ear, number of grains/row, ear grains weight, shelling percentage, 100-grain weight and grain yield/ha. The increases in grain yield when plants were sown at lowest hill spacing $(15 \mathrm{~cm})$ may be due to increase in number of rows/ear and number of grains/ear. These results in good agreement with those reported $[4,26]$. This may be due to more approach uniformity by sown at $15 \mathrm{~cm}$ hill spacing. Therefore, the higher yields obtained with the use of narrow spacing cannot be attributed to a different pattern of leaf area development or a larger leaf surface area to intercept solar radiation. A similar conclusion was reported by those reported by $[1,24]$. The effective interaction between maize hybrids and row width on the 100 grain weight and grain yield/ha significant effected on these traits in both seasons. There were varietal differences in response to intra-row spacing. Grain yield is the product of crop dry matter accumulation and the proportion of the dry matter allocated to the grain and harvest index in corn declines when plant density increases above the critical plant density. Highest grain yield/ha from sown S.C. 3084 at narrow row width (60 $\mathrm{Cm})$ in $20 \mathrm{~cm}$ hill spacing i.e. 59.999 plants/ha reduced competition between, which will be more approached to uniformity which helps sun radiation penetration within plants then increase net photosynthesis, consequently increase grain yield per unite area.

\section{CONCLUSION}

It could be concluded that sown S.C. 3084 hybrid at 60 $\mathrm{cm}$ row width and hill spacing of $20 \mathrm{~cm}$ apart maximized maize productivity under the environmental conditions of Dakahlia Governorate, Egypt.

\section{REFERENCES}

[1] A.I. Sharifai, M. Mahmud, B. Tanimu, and I.U. Abubakar, "Yield and yield components of extra early maize (Zea mays L.) As influenced by intrarow spacing, nitrogen and poultry manure rates" Bayero Journal of Pure and Applied Science, 2012, 5:113-122.

http://www.ajol.info/index.php/bajopas/article/view/ $\underline{80948}$

[2] A.N.E. Attia, S.A. El-Moursy, G.M.A. Mahgoub, and M.M.B. Darwich, "Effect of ridge spacing and plant density for row maize hybrids" Journal Agriculture Science Mansoura University, 2012, 34,8073-8080. http://agrfac.mans.edu.eg/en/projectsresearch/scientific-journal

[3] M.A. Alias, H.A. Bukhsh, R. Ahmad, A.U. Malik, S. Hussain and M. Lshaque, "Argo- physiological traits of three maize hybrids as in flounced by varying plant density" Journal Animal and Plant Science, 2010 , 20,34-39.

http://www.thejaps.org.pk/Volume/2010/20-

1/abstracts/Ahmad_et_al.php

[4] A.E. EL-Metwally, A.A. El-Deeb, S.A. Safina, B.G. Rabbani, "Behavior of some maize hybrids cultivated with different plant densities" Journal Plant Production Mansoura University, 2011, 2,479. 490. http://agrfac.mans.edu.eg/en/projectsresearch/scientific-journal

[5] M.S.I. Zamir, A.H. Ahmad, H.M.R. Javeed and T. Latif, "Growth and yield behavior of two maize hybrids towards different plant spacing. Cercetari Agronomica in Moldova, 2011, 46, 3340.http://www.univagroiasi.ro/CERCET_AGROMOLD/CA2-11-03.pdf

[6] P. Mashiqa, L. Lekgari and S. Ngwako, "Effect of plant density on yield and yield components of maize in Botswana" World of Science Journal, 2012, 1, 173-179. http://www.academicjournals.org/SRE

[7] A.A. Leilah, S.E. El-Kalla, K.A. El-Douby and A.M.K. Abd Rabboh, "Maximizing corn productivity through some modern farming systems. Journal Plant Production Mansoura University, 2013, 4, 561-575. http://www.mans.edu.eg/en/mansoura-universityjournals-en 
[8] E.C. Enuieke, "Effects of variety and spacing on growth characters of hybrids maize. Asian" Journal of Agriculture and Rural Development, 2013, 3, 296-310. http://www.aessweb.com/pdf-files/6-234AJARD-3(5)2013-296-310.pdf

[9] M. Sadeghi, "The determination of plant density on dry matter accumulation, grain yield and yield components of four maize hybrids" International Journal of Agriculture and Crop Science, 2013, 5, 109-114. $\quad$ http://ijagcs.com/wpcontent/uploads/2013/01/109-1141.pdf

[10]E.E.E. Kandil, Response of some maize hybrids (Zea mays L.) to different levels of nitrogenous fertilization. Journal of Applied Science Research,2013, 9, 902-1908. http://www.aensiweb.com/old/jasr/jasr/2013/19021908.pdf

[11] I.A.M. Radma and Y.M.I. Dagash, "Effect of different nitrogen and weeding levels on yield of five maize cultivars under irrigation" Universal Journal of Agriculture Research, 2013, 1, 119-125. DOI: 10.13189/ujar.2013.010401

[12]L. Hejazi and A. Soleymani, "Effect of different amounts of nitrogen fertilizer on grain yield of forage corn cultivars in Isfahan" International Journal of Advanced Biological and Biomedical Research. 2, 2014, 608-614. http://www.ijabbr.com

[13] A. Modhej, A. Kaihani and A. Lack, "Effect of nitrogen fertilizer on grain yield and nitrogen use efficiency in corn (Zea mays L.) hybrids under irrigated conditions. Proceeding National Academy of Science, India, Section B Biological Science, 2014, 4, 531-536. DOI: 10.1007/s40011-013-0254-y

[14]F. Sorkhi and M. Fateh, "Effect of nitrogen fertilizer on yield component of maize" International Journal of Biosciences, 2014, 5, 16-20. http://www.innspub.net/wpcontent/uploads/2014/09/IJB-V5No6-p16-20.pdf

[15] R.H. Zhang, X.H. Zhang, J.J. Camberato and J.Q. Xue, "Photosynthetic performance of maize hybrids to drought stress. Russian Journal Plant Physiology, 2015 , $62,788-796$. http://pleiades.online/en/journal/plntphys/

[16]F. L. Panison, D.F. Sangoi, C.M.M. Kolling, and M.M. Coelho Durli, "Harvest time and agronomic performance of maize hybrids with contrasting growth cycles. Acta Scientiarum. Agronomy Maringá, 2016, 38, 219-226. DOI:10.4025/actasciagron. v38i2.27901

[17] M.M.B. Darwich, "Effect of row spacing and plant density on grow the yield and its component of some new maize hybrids. M.Sc. Thesis, 2009, Fac. of Agric. Mansoura University, Egypt.

[18] O.C. Onyango, "Decreased row spacing as an option for increasing maize (Zea mays L.). Yield in Trans Nzoia district, Kenya" J. of plant Breed. And Crop Sci., 2009, 281-283. http://www.academicjournals.org/journal/JPBCS/arti cle-abstract/8805F0E1141

[19]H.A. El-Mekser, Mosa H.E., Balbaa, M.G., ElGonemy, M.A.M., (2009). Effect of row orientation, row spacing and plant population density on grain yield and other agronomic traits in maize (Zea mays L.). Alexandria Journal Agriculture Research, 54,1727.

http://www.davidpublishing.com/davidpublishing/U pfile/4/15/2012/2012041585703617.pdf

[20] Y.L. Gobeze, G. Michaelceronio and L.D.V. Rensburg, "Effect of row spacing and plant density on yield and yield component of maize (Zea mays L.) under irrigation" Journal of Agriculture Science and Technology, 2B, 2012,263-271. http://www.davidpublishing.com/davidpublishing/U pfile/4/15/2012/2012041585703617.pdf

[21] S. Fahad, S. Saud, H. Muhammad, S. Hassan, A. Shah and F. Ullah, "Effect of row spacing and methods of sowing on the performance of maize" Austin Food Science. 1, 2016, 1-4. www.austinpublishinggroup.com

[22] M.R. Abuzar, G.U. Sadozai, M.S. Baloch, A.A. Baloch, I.H. Shah, T. Javaid and N. Hussain, "Effect of plant population densities on yield of maize". Journal of Animal and Plant Science, 2011, 21, 692695. DOI: 10.2298/BAH1601083M

[23] A.S. Bisht, A. Bhatnagar, M.S. Pal and V. Singh "Growth dynamics, productivity and economics, quality protein maize (Zea mays L.) under varying plant density and nutrient management practices" Madras Agriculture Journal, 2012, 99, 73-76. https://www.cabdirect.org/cabdirect/abstract/201231 98822

[24] J.A. Ukonze, V.O. Akor and U.M. Ndubuaku, "Comparative analysis of three different spacing on the performance and yield of late maize cultivation in Etche local government area of Rivers State, Nigeria" African Journal of Agricultural Research, 2016,11,1187-

1193..http://www.academicjournals.org/journal/AJA R/article-full-text-pdf/A4624BD57856

[25] M.H. Greish and G.M. Yakout, "Effect of plant population density and nitrogen fertilization on yield and yield components of some white and yellow maize hybrids under drip irrigation system in sandy 
soil" Developments in Plant and Soil Sciences, 2001, 92, 810-811. http://link.springer.com/chapter/10.1007\%2F0-30647624-X 394

[26] O. Sener, H. Gozubenli, O. Konuskan and M. Kilinc, "The effects of intra-row spacing on the grain yield and some agronomic characteristics of maize (Zea mays L.) hybrids" Asian Journal of Plant Science, 2004, 3, 429-432. DOI: 10.3923/ajps.2004.429.432

[27] G.M.A. Mahgoub and A.A. El-Shenawy, "Response of some maize hybrids to row spacing and plant density. Proc. of $1^{\text {st }}$ Conf. Field Crop Res. Institute, ARS, 22-24 Aug., 2006, Egypt, P: 285-293.

[28] V. Sofiatti, A. Cargin, L.V.B.C. Silva and J.C.C. Galvao, "Maize population increase and reduce spacing between plant rows. Revista Cientifica Rural, 2007, $12 \quad$ (1), 131-139. http://alerta.cpac.embrapa.br/titulos/revista_cientific a_rural.html

[29] K.A. Gomez and A.A. Gomez, "Statistical Procedures in Agricultural Research. Ed. John Wiley and Sons, 1991, New York, USA. http://pdf.usaid.gov/pdf_docs/PNAAR208.pdf

[30] G.W. Snedecor and W.G. Cochran, "Statistical methods. $7^{\text {th }}$ Ed., Iowa State University Press, 1980, Ames, Iowa, USA. https://www.amazon.com/Statistical-MethodsSeventh-isbn-0813815606/dp/B0012S4NIE

Table.1: Different plant population densities due to row width and hill spacing.

\begin{tabular}{|c|c|c|}
\hline Row width & Hill spacing & Plant populations densities \\
\hline $60 \mathrm{~cm}$ & $15 \mathrm{~cm}$ & 84.000 Plant/ha \\
\hline $60 \mathrm{~cm}$ & $20 \mathrm{~cm}$ & $67.200 \mathrm{Plant} / \mathrm{ha}$ \\
\hline $60 \mathrm{~cm}$ & $25 \mathrm{~cm}$ & $59.999 \mathrm{Plant} / \mathrm{ha}$ \\
\hline $60 \mathrm{~cm}$ & $30 \mathrm{~cm}$ & $96.000 \mathrm{Plant} / \mathrm{ha}$ \\
\hline $70 \mathrm{~cm}$ & $15 \mathrm{~cm}$ & $72.000 \mathrm{Plant} / \mathrm{ha}$ \\
\hline $70 \mathrm{~cm}$ & $20 \mathrm{~cm}$ & $57.600 \mathrm{Plant} / \mathrm{ha}$ \\
\hline $70 \mathrm{~cm}$ & $25 \mathrm{~cm}$ & $48.000 \mathrm{Plant} / \mathrm{ha}$ \\
\hline $70 \mathrm{~cm}$ & $30 \mathrm{~cm}$ & \\
\hline
\end{tabular}


Table.2: Number of ear/plant, number of plants at harvest, ear length, ear diameter and number of rows/ear as affected by maize hybrids, row width and hill spacing as well as their interactions during 2014 and 2015 seasons.

\begin{tabular}{|c|c|c|c|c|c|c|c|c|}
\hline \multirow{2}{*}{ Treatments } & \multicolumn{2}{|c|}{ Number of ear/plant } & \multicolumn{2}{|c|}{$\begin{array}{l}\text { Ear length } \\
\quad(\mathrm{Cm})\end{array}$} & \multicolumn{2}{|c|}{$\begin{array}{l}\text { Ear diameter } \\
(\mathrm{Cm})\end{array}$} & \multicolumn{2}{|c|}{ Number of rows/ear } \\
\hline & 2014 & 2015 & 2014 & 2015 & 2014 & 2015 & 2014 & 2015 \\
\hline \multicolumn{9}{|l|}{ A- Row width: } \\
\hline $60 \mathrm{~cm}$ & 2.14 & 2.14 & 24.89 & 24.79 & 4.21 & 4.17 & 15.81 & 15.81 \\
\hline $70 \mathrm{~cm}$ & 2.17 & 2.25 & 25.07 & 24.89 & 4.27 & 4.25 & 16.20 & 15.87 \\
\hline F. Test & NS & $*$ & $*$ & NS & NS & $*$ & $*$ & NS \\
\hline \multicolumn{9}{|l|}{ B-Maize Hybrids: } \\
\hline SC 3084 & 2.12 & 2.06 & 26.18 & 26.48 & 4.50 & 4.50 & 15.53 & 15.56 \\
\hline SC 3062 & 2.00 & 2.15 & 23.62 & 22.90 & 4.30 & 4.26 & 15.37 & 15.37 \\
\hline SC 2055 & 2.25 & 2.56 & 25.09 & 24.89 & 4.05 & 4.04 & 16.68 & 16.31 \\
\hline SC 2066 & 2.25 & 2.00 & 25.03 & 25.09 & 4.10 & 4.04 & 16.43 & 16.12 \\
\hline F. Test & $*$ & $*$ & $*$ & $*$ & $*$ & $*$ & $*$ & $*$ \\
\hline LSD at $5 \%$ & 0.22 & 0.18 & 0.54 & 0.36 & 0.11 & 0.08 & 0.57 & 0.40 \\
\hline \multicolumn{9}{|l|}{ C-Hill spacing: } \\
\hline $15 \mathrm{~cm}$ apart & 1.90 & 2.06 & 24.23 & 24.32 & 4.22 & 4.23 & 16.00 & 16.12 \\
\hline $20 \mathrm{~cm}$ apart & 2.31 & 2.09 & 25.18 & 24.85 & 4.21 & 4.16 & 16.03 & 15.81 \\
\hline $25 \mathrm{~cm}$ apart & 2.21 & 2.28 & 25.29 & 25.12 & 4.22 & 4.19 & 16.06 & 15.75 \\
\hline $30 \mathrm{~cm}$ apart & 2.18 & 2.34 & 25.21 & 25.05 & 4.30 & 4.26 & 15.93 & 15.68 \\
\hline F. Test & $*$ & $*$ & * & $*$ & $*$ & $*$ & NS & $*$ \\
\hline LSD at $5 \%$ & 0.21 & 0.19 & 0.33 & 0.30 & 0.06 & 0.06 & - & 0.34 \\
\hline \multicolumn{9}{|l|}{ D-Interactions F-Test: } \\
\hline $\mathrm{A} \times \mathrm{B}$ & NS & NS & $*$ & NS & $*$ & NS & NS & NS \\
\hline $\mathrm{A} \times \mathrm{C}$ & NS & NS & NS & NS & $*$ & NS & NS & NS \\
\hline $\mathrm{B} \times \mathrm{C}$ & NS & NS & NS & $*$ & NS & $*$ & NS & $*$ \\
\hline $\mathrm{A} \times \mathrm{B} \times \mathrm{C}$ & NS & NS & NS & $*$ & NS & $*$ & NS & NS \\
\hline
\end{tabular}


Table.3: Number grains/row, grains weight/ear, shelling, 100-grain weight and grain yield/fed as affected by maize hybrids, row width and hill spacing as well as their interactions during 2014 and 2015 seasons.

\begin{tabular}{|c|c|c|c|c|c|c|c|c|}
\hline \multirow{2}{*}{ Treatments } & \multicolumn{2}{|c|}{ Number of ear/plant } & \multicolumn{2}{|c|}{$\begin{array}{c}\text { Ear length } \\
(\mathrm{Cm})\end{array}$} & \multicolumn{2}{|c|}{$\begin{array}{c}\text { Ear diameter } \\
(\mathrm{Cm})\end{array}$} & \multicolumn{2}{|c|}{ Number of rows/ear } \\
\hline & 2014 & 2015 & 2014 & 2015 & 2014 & 2015 & 2014 & 2015 \\
\hline \multicolumn{9}{|l|}{ A- Row width: } \\
\hline $60 \mathrm{~cm}$ & 50.37 & 50.12 & 294.2 & 288.8 & 87.98 & 85.11 & 40.07 & 39.76 \\
\hline $70 \mathrm{~cm}$ & 50.62 & 49.89 & 295.0 & 293.4 & 88.13 & 87.97 & 41.42 & 41.17 \\
\hline F. test & NS & NS & NS & NS & $*$ & $*$ & $*$ & $*$ \\
\hline \multicolumn{9}{|l|}{ B-Maize Hybrids: } \\
\hline SC 3084 & 51.31 & 51.31 & 322.0 & 321.5 & 88.73 & 87.94 & 45.59 & 45.62 \\
\hline SC 3062 & 47.09 & 47.00 & 290.1 & 281.0 & 87.76 & 87.65 & 43.34 & 42.81 \\
\hline SC 2055 & 51.71 & 51.31 & 284.2 & 281.8 & 88.17 & 83.22 & 36.40 & 35.93 \\
\hline SC 2066 & 51.87 & 50.40 & 282.1 & 280.0 & 87.55 & 87.35 & 37.65 & 37.50 \\
\hline F. test & $*$ & $*$ & $*$ & $*$ & $*$ & $*$ & $*$ & $*$ \\
\hline LSD at $5 \%$ & 0.76 & 0.68 & 7.9 & 9.1 & 0.42 & 0.47 & 1.32 & 1.17 \\
\hline \multicolumn{9}{|l|}{ C- Hill spacing: } \\
\hline $15 \mathrm{~cm}$ apart & 50.71 & 50.56 & 289.8 & 280.0 & 87.64 & 86.01 & 39.87 & 38.90 \\
\hline $20 \mathrm{~cm}$ apart & 50.62 & 49.71 & 291.2 & 287.9 & 88.06 & 83.83 & 40.46 & 40.31 \\
\hline $25 \mathrm{~cm}$ apart & 50.34 & 49.68 & 291.2 & 291.7 & 88.03 & 87.88 & 40.59 & 40.15 \\
\hline $30 \mathrm{~cm}$ apart & 50.31 & 50.06 & 306.2 & 304.8 & 88.48 & 88.43 & 42.06 & 42.50 \\
\hline F. Test & NS & $*$ & $*$ & $*$ & $*$ & $*$ & $*$ & $*$ \\
\hline LSD at $5 \%$ & - & 0.51 & 5.4 & 6.8 & 0.39 & 0.58 & 1.05 & 0.95 \\
\hline \multicolumn{9}{|l|}{ D-Interactions F-Test: } \\
\hline $\mathrm{A} \times \mathrm{B}$ & NS & NS & $*$ & NS & NS & $*$ & $*$ & $*$ \\
\hline $\mathrm{B} \times \mathrm{C}$ & $*$ & NS & NS & $*$ & NS & $*$ & $*$ & $*$ \\
\hline $\mathrm{B} \times \mathrm{C}$ & NS & $*$ & NS & $*$ & NS & $*$ & $*$ & $*$ \\
\hline $\mathrm{A} \times \mathrm{B} \times \mathrm{C}$ & $*$ & NS & $*$ & NS & $*$ & NS & NS & $*$ \\
\hline
\end{tabular}




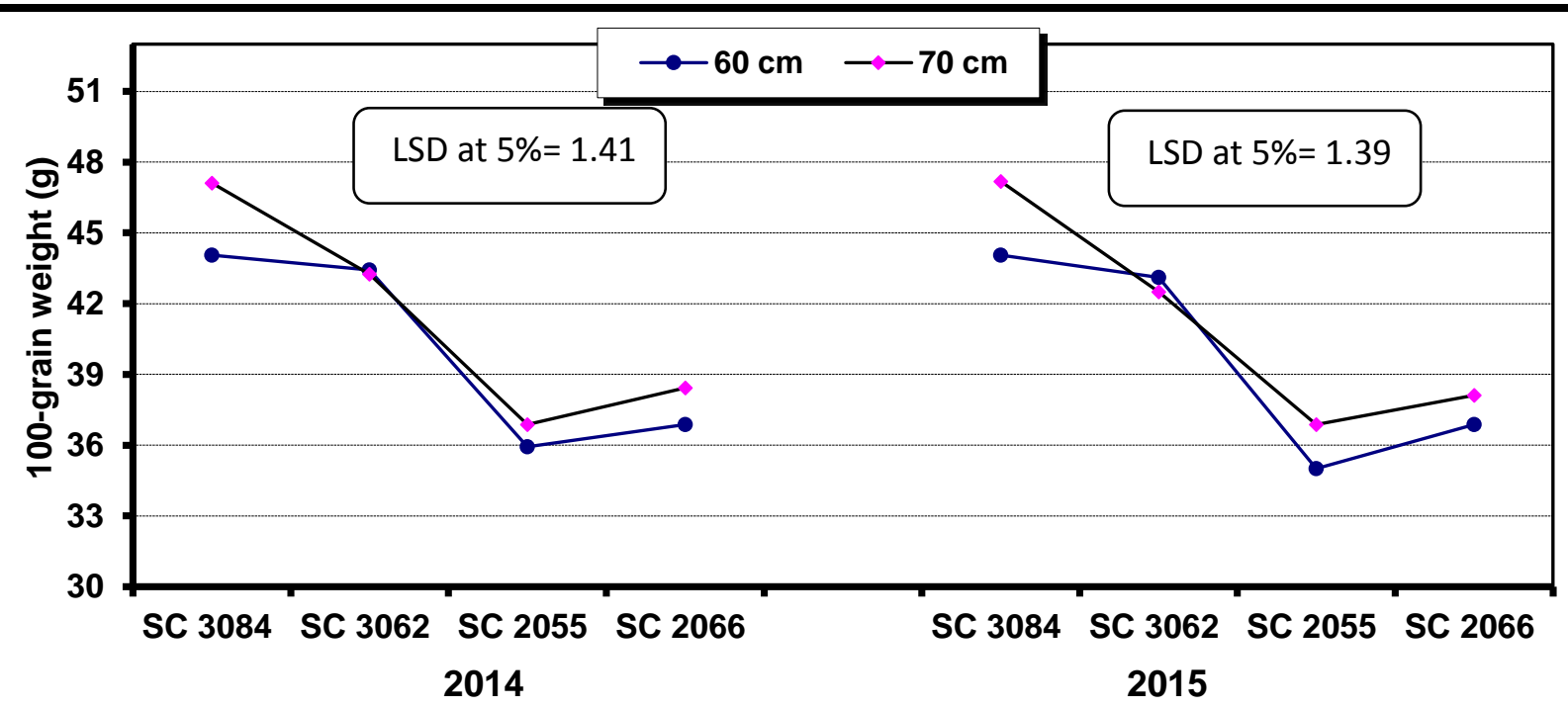

Fig.1: 100-grain weight (g) as affected by the interaction between maize hybrids and row width during 2014 and 2015 seasons.

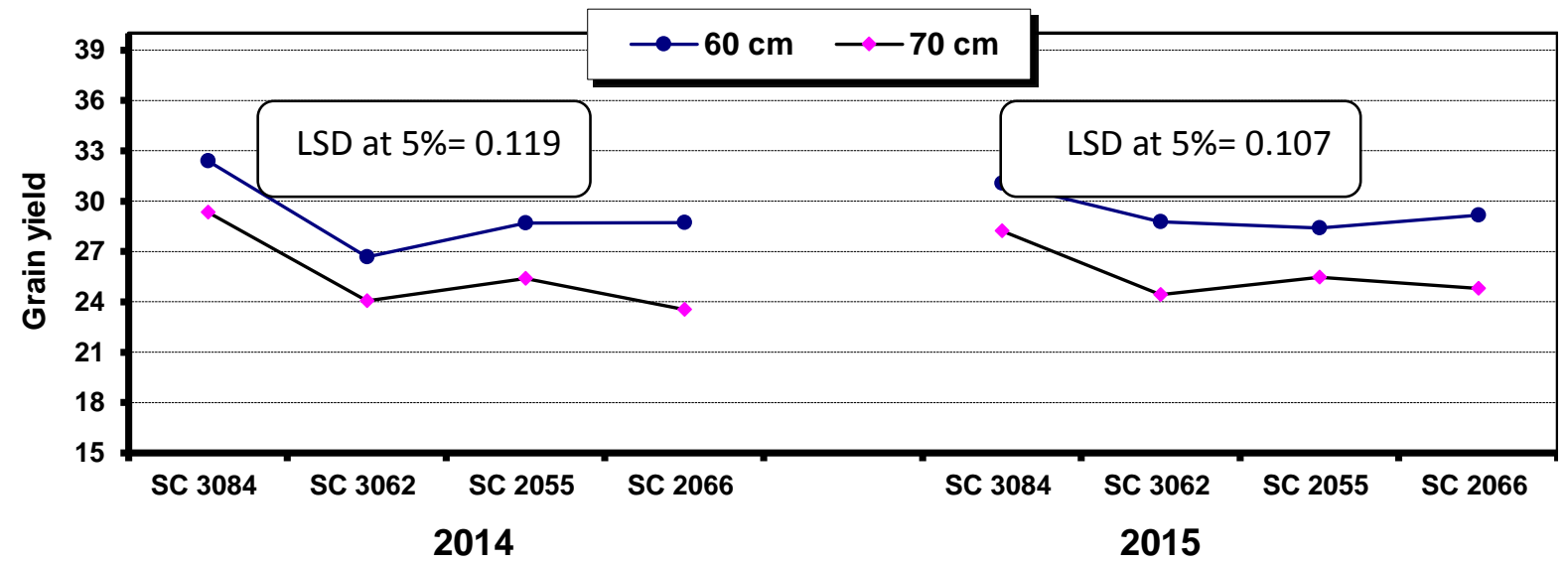

Fig. 2: Grain yield/ha as affected by the interaction between maize hybrids and row width during 2014 and 2015 seasons.

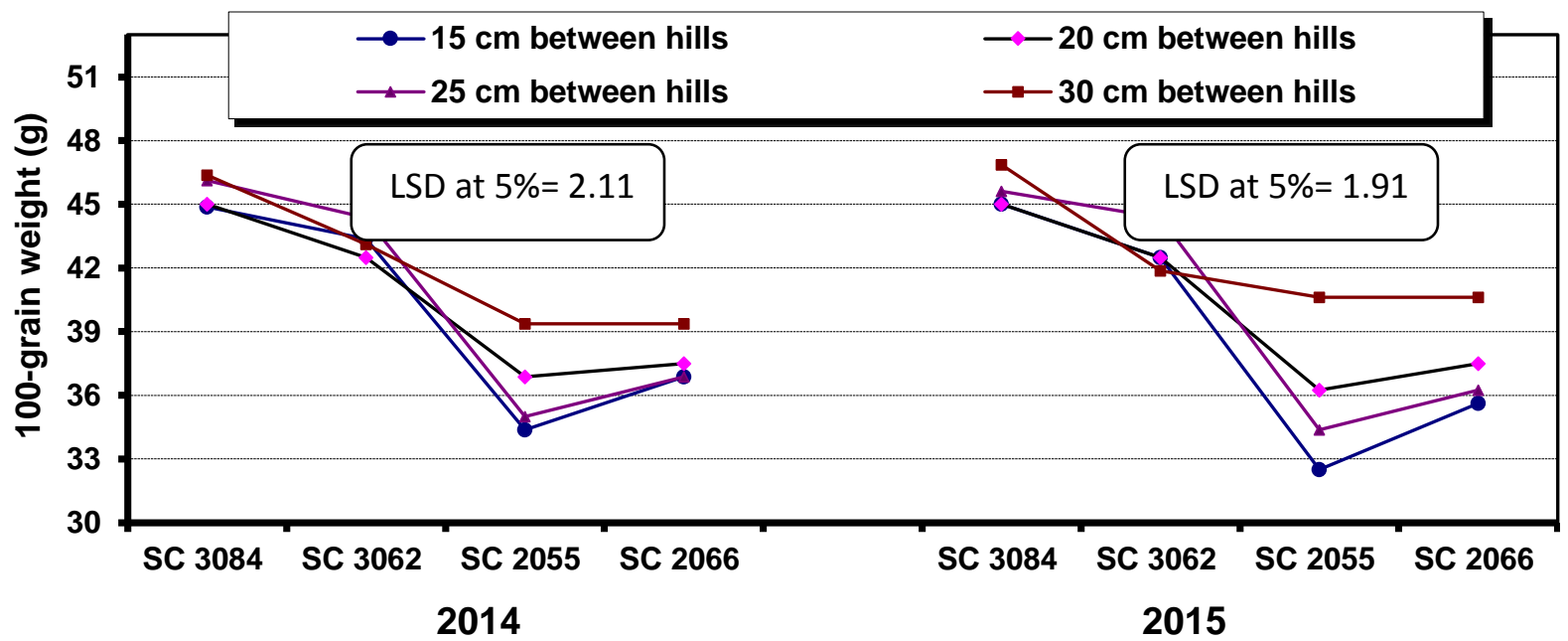

Fig.3: 100-grain weight (g) as affected by the interaction between maize hybrids and hill spacing during 2014 and 2015 seasons. 


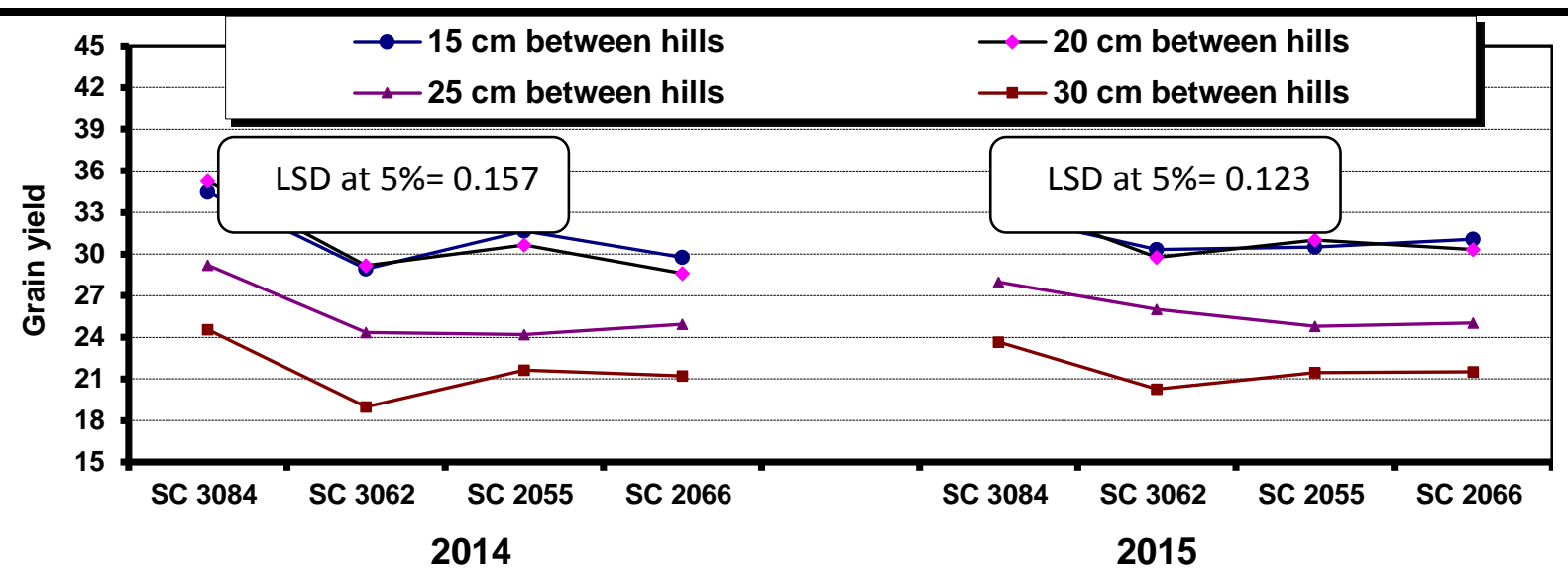

Fig.4: Grain yield/ha as affected by the interaction between maize hybrids and hill spacing during 2014 and 2015 seasons.

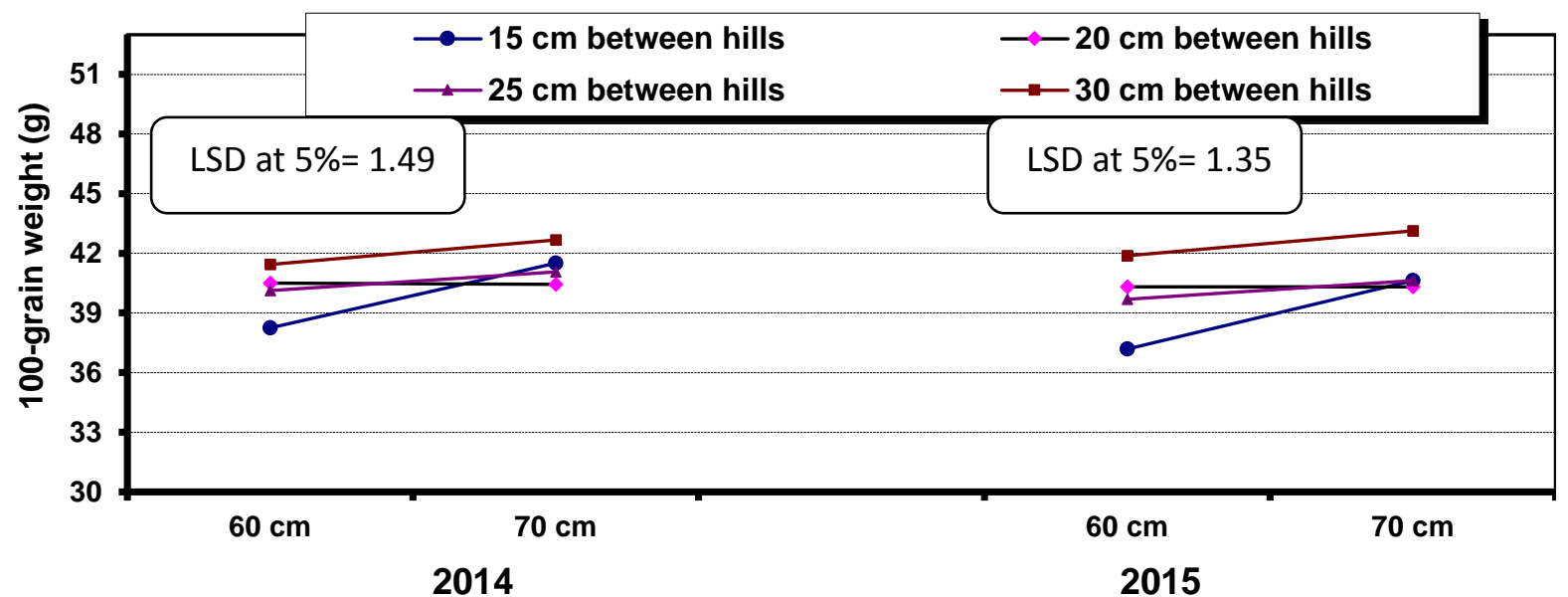

Fig. 5: 100-grain weight ( $g$ ) as affected by the interaction between row width and hill spacing during 2014 and 2015 seasons.

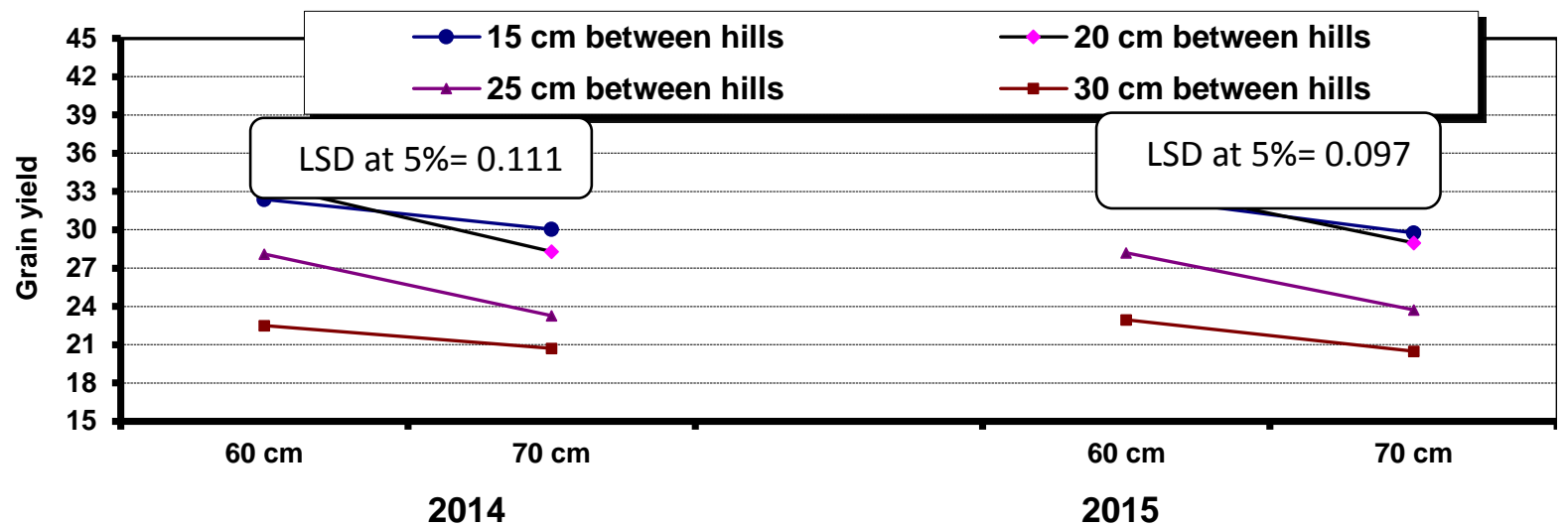

Fig.6: Grain yield/ha as affected by the interaction between row width and hill spacing during 2014 and 2015 seasons. 